\title{
Effects of Three Levels of N, P, K on the Growth of Sander's Dracaena (D. sanderiana Hort. $)^{1}$
}

\author{
Saulo J. Rodríguez and Carlos Rivera-López ${ }^{2}$
}

\begin{abstract}
Sander's Dracaena (Dracaena sanderiana, Hort.) was grown in $3 \times 3 \times 3 \mathrm{~N}, \mathrm{P}$, $\mathrm{K}$ factorial experiment in a 1:1 mixture of peatmoss and Cataño sand. Commercial cuttings were harvested at regular intervals during a 32-mo growing period. Fresh weight, length, number of leaves, and weight of leaves was recorded from each harvested cutting.

Nitrogen affected significantly the number of harvested cuttings per unit area, total growth and total top growth, all of which were highest at 600 pounds of N/ acre/yr. Phosphorus affected significantly only the number of harvested cuttings while potassium affected significantly total growth, top growth, root growth, mean size and mean weight of harvested cuttings, and leaf mean weight. The fitting of a modification of the fertilizer-yield equation $Y=A / 1+B(C-X)^{2}$ showed that maximum yields in terms of number of cuttings were obtained with a combination of approximately 648,465 and 583 pounds of N, P, K/acre/yr, respectively.

The maximum total growth and top growth depended more on the phosphorus and less on the potassium. Root growth was definitely affected by the phosphorus applications.
\end{abstract}

\section{INTRODUCTION}

The commercial production of foliage plants for exportation is an important agricultural enterprise with a bright future. GonzálezVillafañe and Cucalón (4) determined that a total of 6,575,763 units of ornamental plants were exported during the year 1971-72, of which 2,633,441 were Sander's Dracaena (D. sanderiana, Hort.). The gross value of exportation was calculated at $\$ 906,347$ for all ornamental plants, $\$ 261,309$ of which was from Sander's Dracaena. Moreover, the Plant Quarantine Section of the Department of Agriculture in July 1974 had 20 registered nurseries covering an approximate total of 226 acres, an indication of the high intensive use of land devoted to ornamental foliage plants (5).

Sander's Dracaena is exported as unrooted, rooted and foiled cuttings, potted plants and canes. The size of the material depends on the demand for a certain type of Dracaena, which is used for exterior and interior decoration, but preferably under shade. In spite of its importance, little research has been done in Puerto Rico and elsewhere with this plant. The work by Samuels and Cibes (2) and Cibes and Samuels (3) on the

\footnotetext{
${ }^{1}$ Manuscript submitted to Editorial Board April 22, 1976.

${ }^{2}$ Horticulturist and Former Agronomist, Plant Breeding Department, Agricultural Experiment Station, Mayaguez Campus, University of Puerto Rico, Rio Piedras, P.R. The suggestions of Dr. B. G. Capó, Technical Consultant as well as the assistance of Mr. Mariano Antoni, Statistics Section, are deeply appreciated.
} 
correction of an iron chlorosis and on the patterns of mineral deficiency symptoms reflected by Sander's Dracaena under greenhouse conditions are the only reports on the subject.

This paper reports the effect of three levels each of $\mathrm{N}, \mathrm{P}$, and $\mathrm{K}$ on the growth of Sanders's Dracaena.

\section{PROCEDURES}

Three rooted cuttings were planted in 5-gal porcelain crocks that contained a 1:1 mixture of peatmoss and Cataño sand. Each rooted cutting measured 9 in $(22.8 \mathrm{~cm})$ long with a mean weight of $18 \mathrm{~g}$.

The three levels of $\mathrm{N}, \mathrm{P}$, and $\mathrm{K}$ were factorially combined to form a total of 27 treatments. The treatments were distributed in five replications following a randomized block design. Each yearly application was split into four 3-mo applications. The first one was mixed with the original Cataño sand-peatmoss mixture. The subsequent treatments were applied evenly to the surface with perlite as the carrier.

The first stalks were harvested 3 mo after planting. All stalks were cut at $4 \frac{1}{2}$ inches from the surface. Thereafter, they were harvested every time the suckers had reached a commercial size. Aerial suckers were harvested leaving $2^{1 / 2}$ inches from the point of attachment. All ground suckers were harvested in the same way and size as the original cuttings. The experiment covered a period of 32 mo.

Fresh weight of the whole cutting, fresh leaf weight, number of leaves, length of the stem from the cut surface to the last visible internode were recorded for each cutting. The third, fourth, fifth and sixth leaves were separated for chemical analyses.

All information was analyzed statistically through variance and a modification of the fertilizer-yield equation

$$
Y=\frac{A}{\left[1+B(C-\mathrm{X})^{2}\right]}
$$

as suggested by Capó (1). The modified fertilizer-yield equation was

$$
Y=\frac{A}{\left[1+B_{N}\left(C_{N}-\mathrm{X}_{\mathrm{N}}\right)^{2}\right]\left[1+B_{P}\left(C_{P}-\mathrm{X}_{\mathrm{P}}\right)^{2}\left[1+B_{K}\left(C_{K}-\mathrm{X}_{\mathrm{K}}\right)^{2}\right]\right.}
$$

in which $\mathrm{X}_{\mathrm{N}}, \mathrm{X}_{\mathrm{P}}$ and $\mathrm{X}_{\mathrm{K}}$ are the applied quantities of $\mathrm{N}, \mathrm{P}$ and $\mathrm{K} ; C_{N}, C_{P}$ and $C_{K}$ are the quantities of $\mathrm{N}, \mathrm{P}$ and $\mathrm{K}$ which when applied will be conducive to maximum yields. $B_{N}, B_{P}$ and $B_{K}$ are indexes of variability of the crop yield as the quantities of the respective nutrients differ from their optimum applications. The fitting of the curve was evaluated both by testing the significance of the coefficient of determination and through chi $^{2}$. 


\section{RESULTS AND DISCUSSION}

The main effects of the three major nutrients on growth and quality of Sander's Dracaena are presented in table 1. The number of harvested cuttings, total growth, and top growth were affected significantly by the application of nitrogen, as was expected. The curvilinear response was higher with the intermediate $600-\mathrm{lb} \mathrm{N}$, and lower at the no-nitrogen and at the 1200-lb $\mathrm{N}$ levels. This finding is in accordance with most of the results with nitrogen fertilization in other crops, in which there is a positive response up to a certain level, above which there is a definite drop. Total root growth, number of leaves per cutting, and the cuttings' mean weight and mean length were not statistically affected by nitrogen applications. The same held true for the foliage/stem and stem/root relationships.

On the other hand, the leaf mean weight was significantly higher at the no-nitrogen level as compared to the 600 and 1,200 lb/acre levels. As in a factory, the production may be stabilized either by better flow of natural resources or by increasing the manufacturing surface. That may be the explanation for the larger leaves in the no $\mathrm{N}$ treatment. The same effects were observed with the same plant at different shade intensities. ${ }^{3}$

The $\mathrm{P}$ applications did not affect the different parameters measured, except the number of harvested cuttings per unit area (table 1), good news for the farmer, who wants more cuttings per unit area without their size being affected.

The number of cuttings per unit area increased significantly with the application of $400 \mathrm{lb}$ of $\mathrm{K} / \mathrm{acre} / \mathrm{yr}$ as compared to the 0 - and the $200-\mathrm{lb}$ applications. The 200-lb application significantly affected total growth, top, and root growth of the plants (table 1). Contrary to $\mathrm{N}$ and $\mathrm{P}$ applications, $\mathrm{K}$ affected significantly the mean weight of cuttings and the mean leaf weight as well. The highest mean weight per cutting was obtained at $400 \mathrm{lb}$ per acre, while the best leaf mean weight, was obtained at the 200 and $400 \mathrm{lb}$ levels. The number of leaves per cutting, the foliage/ stem and stem/root ratios were not significantly affected by the potassium levels.

The expected values obtained by the application of the ferilizer-yield equation are presented in table 2. The coefficient of determination and the $R$ values obtained were significant or highly significant, suggesting that the equation provided a satisfactory explanation of the yield variation. This was corroborated by the $\mathrm{chi}^{2}$ test for goodness of fit. Both tests agreed only with regard to the number of harvested cuttings per unit area.

The maximum number of cuttings (1385.5) were obtained by the application of 648,465 and $583 \mathrm{lb}$ of $\mathrm{N}, \mathrm{P}$ and $\mathrm{K}$, respectively. The

${ }^{3}$ S. J. Rodríguez and C. Rivera-López, unpublished data. 
TABLE 1.-The main effects of $N, P$, and $K$ levels in a $3 \times 3 \times 3$ factorial experiment with Dracaena sanderiana, Hort.

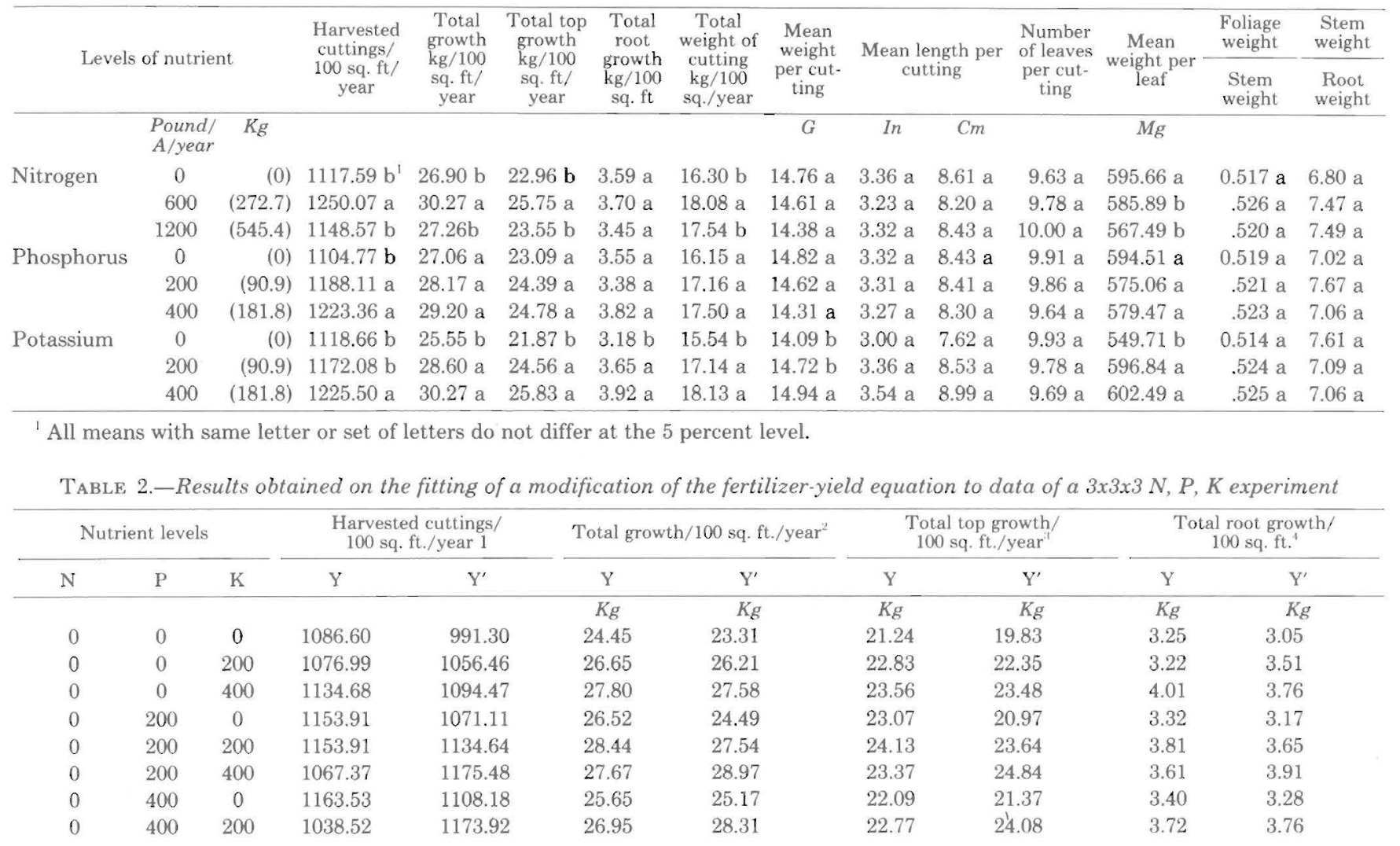




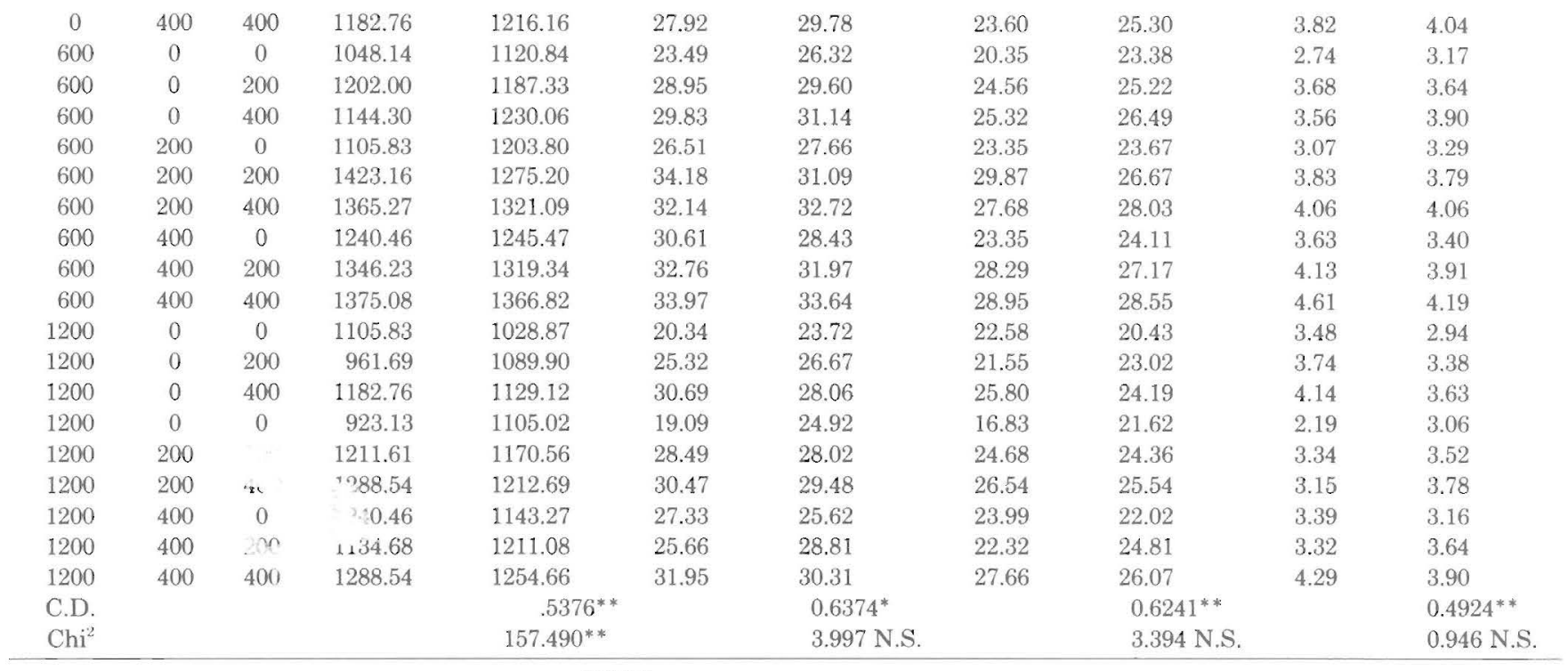

${ }^{1} \mathrm{Y}=\frac{1385.5}{\left[1+0.0029641\left(\mathrm{X}_{\mathrm{N}}-6.4851\right)^{2}\right]\left[1+0.0052566\left(\mathrm{X}_{\mathrm{p}}-4.649\right)^{2}\right]\left[1+0.0032167\left(\mathrm{X}_{\mathrm{K}}-5.8260\right)^{2}\right]}$

${ }^{2} \mathrm{Y}=\frac{33.861}{\left[1+0.0033221\left(\mathrm{X}_{\mathrm{N}}-6.2457\right)^{2}\right]\left[1+0.0030157\left(\mathrm{X}_{\mathrm{p}}-5.3343\right)^{2}\right]\left[1+0.0098507\left(\mathrm{X}_{\mathrm{K}}-4.3260\right)^{2}\right]}$

${ }^{3} \mathrm{Y}=\frac{28.582}{\left[1+0.0031037\left(\mathrm{X}_{\mathrm{N}}-6.4473\right)^{2}\right]\left[1+0.0050261\left(\mathrm{X}_{\mathrm{p}}-3.9282\right)^{2}\right]\left[1+0.010325\left(\mathrm{X}_{\mathrm{K}}-4.2287\right)^{2}\right]}$

${ }^{4} \mathrm{Y}=\frac{4.44125}{\left[1+0.0015854\left(\mathrm{X}_{\mathrm{N}}-5.0205\right)^{2}\right]\left[1+0.0011576\left(\mathrm{X}_{\mathrm{p}}-10.331\right)^{2}\right]\left[1+0.011248\left(\mathrm{X}_{\mathrm{K}}-4.5923\right)^{2}\right]}$ 
maximum total growth $\left(33.861 \mathrm{~kg} / 100 \mathrm{ft}^{2} /\right.$ year $)$ was obtained with applications of 624,533 and 432 pounds of $\mathrm{N}, \mathrm{P}$ and $\mathrm{K}$, respectively. At the same time the maximum top growth was obtained with 645,393 and 423 lb of N, P and K, while maximum root growth was obtained with 502, 1033 and $459 \mathrm{lb}$ of the above mentioned nutrients.

The results suggested that $\mathrm{N}$ and $\mathrm{K}$ are the two most important major nutrients for Sander's Dracaena but $\mathrm{P}$ seems to be a determining factor in the number of cuttings to harvest from a given area and root growth as well. Potassium may affect the quality of the cutting because of its effect on size of leaves and cuttings. This fact means shifting the production to either a small or a large cutting may be controlled by $\mathrm{K}$ nutrition.

\section{RESUMEN}

El efecto que podrian tener cantidades de nitrógeno, fósforo y potasio en el crecimiento, tamaño y apariencia de esquejes comerciales de la planta ornamental Dracaena de Sander (Dracaena sanderiana Hort.) se estudió en un diseño factorial $3 \times 3 \times 3$.

Esquejes arraigados de 9 pulgadas de largo y con un peso medio de $18 \mathrm{~g}$ se sembraron en una mezcla de partes iguales de turba de pantano y arena Cataño. Los tres nutrimentos se aplicaron de la siguiente manera: nitrógeno, 0, 600 y 1200 libras por acre y año; fósforo, 0 , 200 y $400 \mathrm{lb}$.; potasio, 200 y $400 \mathrm{lb}$. El abono total de cada análisis se dividió en cuatro aplicaciones iguales, una cada 3 meses.

La primera cosecha de esquejes comerciales se efectuó a los 3 meses después de la siembra, cortando la planta a una altura de $4 \frac{1}{2}$ pulgadas de la superficie de la mezcla turbaarena. De ahí en adelante, los brotes de tamaño comercial se cortaron a $2 \frac{1 / 2}{2}$ pulgadas de la planta madre, pero los que se desarrollaron al nivel de la mezcla se cortaron también a $41 / 2$ pulgadas. En cada corte se anotaron el peso fresco, número y peso de las hojas y la apariencia de cada esqueje. Al terminar el estudio se cosecharon el resto del tallo y las raices.

Estos datos se sometieron a un análisis de varianza y a una modificación de la ecuación abono-rendimiento

$$
Y=\frac{A}{\left[1+B(C-\mathrm{X})^{2}\right]}
$$

El análisis demostró que el nitrógeno aumentó el número de esquejes por área unitaria y a la vez afectó favorablemente el crecimiento, obteniéndose los mejores resultados con la aplicación de $600 \mathrm{lb}$. por acre y año. Sin embargo, el nitrógeno no afectó significativamente los demás parámetros estudiados. El fósforo y el potasio también aumentaron el número de esquejes por área unitaria, pero además, el potasio aumentó significativamente el crecimiento total, asi como el de las cañas, hojas y raíces; y el tamaño y el peso medio tanto de los esquejes como de las hojas. La aplicación de la modificación de la ecuación abonorendimiento explica bastante bien los resultados. De hecho, los rendimientos más elevados en cuanto al número de esquejes cosechados por unidad de área se obtuvo con aplicaciones de 648,465 y 583 libras de N, P y K, respectivamente. Sin embargo, en cuanto al peso total y al de los tallos y hojas, la necesidad de fósforo aumentó mientras que la del potasio disminugyó. Con respecto al desarrollo de las ráices, definitivamente la necesidad de fósforo aumentó hasta el doble.

\section{LITERATURE CITED}

1. Capó B. G., 1967. Additional evidence on the applicability of the new fertilizer-yield relation, J. Agri. U.P.R. 51(2): 97-120.

2. Cibes, H. and Samuels, G., 1960. Mineral deficiency symptoms displayed by Dracaena godseffiana and Dracaena sanderiana grown under controlled contitions, Tech. Paper 29, Agri. Exp. Stn., Univ. P.R., Río Piedras, P.R., 28 pp. 
3. González-Villafañe, E. and Cucalón, M., 1974. Análisis de las importaciones y exportaciones de plantas ornamentales y flores en Puerto Rico, Bul. 235, Esta., Exp. Agri., Univ. P.R., Rio Piedras, P.R.,

4. Samuels, G. and Cibes, H., 1953. Iron chlorosis on Dracaena sanderiana, J. Agri. Univ. P.R. 37(4): 265-72.

5. Plant Quarantine Section, 1974. Registered nurseries in Puerto Rico for year 1974-75, Commonwealth Dep. Agri., Area of Specialized Services. 